\title{
Effect of ethanol consumption on colon cancer in an experimental model
}

\author{
S. Pérez-Holanda, L. Rodrigo ${ }^{1}$, J. Viñas-Salas ${ }^{2}$ and C. Piñol-Felis ${ }^{2}$ \\ Department of Surgery. Hospital Grande Covián. Arriondas. Asturias. ${ }^{1}$ Department of Medicine. Faculty of Medicine. \\ University of Oviedo. Asturias. ${ }^{2}$ Department of Medicine and Department of Surgery. Faculty of Medicine. University \\ Hospital Arnau de Vilanova. University of Lleida. Spain
}

Pérez-Holanda S, Rodrigo L, Viñas-Salas J, Piñol-Felis C. Effect of ethanol consumption on colon cancer in an experimental model. Rev Esp Enferm Dig 2003; 95: 87-96.

\begin{abstract}
Aims: the present study was designed to examine the effect of an ethanol supplement on experimental colon carcinogenesis.

Material and methods: one hundred and ten 10-week-old Sprague-Dawley rats were divided into five groups: group $\mathrm{A}$ (20 rats) received no treatment. Group B (20 rats) received a supplement of ethanol at $1.23 \mathrm{~g} / \mathrm{kg}$ of body weight per day added to their drinking water for 24 weeks. Group C (30 rats) received 18 weekly doses of dimethylhydrazine (DMH) at $21 \mathrm{mg} / \mathrm{kg}$ of body weight from the beginning of the study. Group D (20 rats) received ethylen-diamin-tetracetic acid (EDTA) solution only for 18 weeks. Group E (20 rats) received ethanol at the same dose as group $\mathrm{B}$ plus $\mathrm{DMH}$ injections at the same dose as the rats in group $C$ from the beginning of the study. All experimental animals were sacrified after 25-27 weeks.

Results: no significant differences in the number of rats that developed tumors, number of tumor-free animals, and number of tumors per rat, as well as in macro-microscopic tumoral findings were observed for animals in group $\mathrm{C}$ compared to animals in group E.

Conclusions: we concluded that the addition of an ethanol supplement does not modify colorectal carcinogenesis using a dynamic model of tumor induction with $\mathrm{DMH}$.
\end{abstract}

Key words: Alcohol. Cancer. Carcinogenesis. Colon. Dimethylhydrazine. Ethanol. Neoplasm. Tumors.

Recibido: 09-01-04.

Aceptado: 14-07-04.

Correspondencia: S. Pérez-Holanda. Castiello, 22, 33394 Gijón. Asturias. Tel.: 985132 948. Fax: 985134 108. e-mail: direccionmedica.gae6@sespa.princast.es

\section{INTRODUCTION}

Colorectal cancer (CRC) is a frequent tumor with a high mortality in western countries (1), where alcohol intake is a common habit. In meta-analyses, environmental factors play a role in the promotion of this tumor (2). In fact, its incidence rate could be reduced approximately by $30-35 \%$ by modifying dietary habits (3).

In an important paper related to epidemiologic evidence published in 1992 (4), an association between alcohol consumption and CRC was reported. More recently, while some clinical studies support that ethanol intake increases the risk of CRC (5-8), other report no relationship $(9,10)$, while others suggest adenoma-promoting effects only (11). It is difficult to perform a long-term prospective study on the influence of different environmental factors in human colon cancer (12). Nevertheless, they report some contradictory results, supporting cancer promotion (13) or adenoma promotion only (14). On other hand, experimental studies have shown an increased risk of CRC due to the effect of alcohol both in vitro (15) and in rodent models $(16,17)$.

Colonic carcinogenesis induced with 1,2 dimethylhydrazine (DMH) in rats has proven to be a close and valuable experimental model of human disease because DMH-induced tumors resemble human colorectal cancer both macro-microscopically and in their clinical behavior (18-20).

The aim of the present study is to investigate the effect of ethanol consumption on experimental colon carcinogenesis using a dynamic model with concomitant administration of alcohol and DMH.

\section{MATERIAL AND METHODS}

Previous studies $(21,22)$ have shown that the number of tumor-free animals was $10-24 \%$, and the number of tu- 
mors per rat was 1.87 . The mortality rate was high in this experimental model $(23,24)$. Other studies report the same allocation in the number of animals in each group (25).

One hundred and ten 10-week-old Sprague-Dawley rats (Lab. Letica ${ }^{\circledR}$, Barcelona, Spain), 55 males and 55 females of identical strain, were allocated to one of five groups with equal gender distribution. The 20 rats in group A (control group) received no treatment. The 20 rats in group B (ethanol control group) received ethanol at $1.23 \mathrm{~g} / \mathrm{kg}$ of body weight (wt) per day added to the drinking water from the beginning until the conclusion of the experiment. Group C was composed of 30 rats due to the high mortality rate obtained in previous studies $(22,24)$. These rats in group $\mathrm{C}$ (ethanol control group) were injected subcutaneously (s.c.) with 18 weekly doses of $21 \mathrm{mg} / \mathrm{kg}$ of body wt of 1,2 dimethylhydrazine (DMH; Fluka Chemica A.G., Sigma Co. ${ }^{\circledR}$, St. Louis, Missouri, U.S.A.) from the beginning of the study to week 27. DMH was prepared, as in previous studies, using a dilution of $400 \mathrm{mg}$ of $\mathrm{DMH}$ in distilled water, containing $37 \mathrm{mg}$ of ethylenediaminetetracetic acid (EDTA; Farmitalia Carlo Erba S.P.A. ${ }^{\circledR}$ Milano, Italy) solution as a stabilizing agent, and using $0.1 \mathrm{M}$ sodium hidroxyde buffer for $\mathrm{pH} 6.5$ (22). The solution was prepared weekly prior to injection into the lumbar region of the rat. The 20 rats in group D (EDTA control group) received the same volume of EDTA solution only. The 20 rats in group E (DMH + ethanol group) were treated with 18 weekly s.c. injections of $21 \mathrm{mg}$ of $\mathrm{DMH} / \mathrm{kg}$ of body wt, and $1.23 \mathrm{~g} / \mathrm{kg}$ per day of ethanol added to the drinking water, beginning at the same time as the first weekly injection of DMH and up to the end of the study. Daily ethanol intake was quantified by controlling daily drinking water consumption.

All rats were fed on standard rodent diet (ITM-R20, Lab. Letica $^{\circledR}$, Barcelona, Spain) with 3\% fat and 5\% starch. Daily food consumption by treated groups was controlled throughtout the study. Fifty percent of animals were weighed weekly until sacrificed. The dose of ethanol given to rats was strictly controlled in order to prevent dehydration when adding alochol to drinking water as observed by others authors (26). Temperature and humidity were controlled throughout the study period in the room where animals were kept, with a 12-hour light schedule $(27,28)$. Animals were lodged in cages with a maximum number of three per cage in order to avoid cannibalism, and to control oral consumption of ethanol as in previous studies (22-24).

European Ethical Committee's recommendations (E. E. C. Directives 1986/609) were followed throughout the study.

Surviving rats were sacrificed at weeks 25 to 27 with a lethal intraperitoneal innoculation of $4.5 \%$ chloral hydrate. In order to avoid the time effect variability, a fixed number of rats from each group were sacrificed during the same week (22).
At autopsy, thoracic and abdominal cavities were examined. The colon and rectum were removed, opened along the antimesenteric border, and gently cleaned of residue with water. The entire gastrointestinal tract was palpated for tumors, adhesions or other abnormalities. The number of tumors, and their location and size were all recorded. Tumors and normal colonic mucosa specimens were taken from the cecum and ascending (right) colon, and specimens from the transverse and descending colon and rectum (left colon) were removed and fixed in $10 \%$ buffered formalin, embedded in paraffin, sectioned, and stained with hematoxylin and eosin for histological observation. Mucosal lesions were classified following criteria by Grau de Castro-Piqué Badía (29) and Lev (30). Tumors obtained were classified according to extent of invasion and differentiation, morphology (considering a mucinous carcinoma when the mucinous component was $>50 \%$ ), tumor size and macroscopic appearance, and the presence of associated lymphoid tissue. Small-bowel tumors and other extraintestinal findings were also noted.

A Chi square test was performed on the DMH and $\mathrm{DMH}+$ ethanol groups in order to compare tumor incidence, anatomopathological findings, total colorectal tumors, left versus right colon tumor totals, average tumor size, and tumor association with lymphoid tissue. In the event that conditions for the application of the Chi square test were not fulfilled, Fisher's exact test was used. The differences between both groups were significant when the $\mathrm{p}$ value was less than or equal to 0.05 . Results are presented as mean (average) \pm standard deviation (SD).

\section{RESULTS}

Six rats $(5.5 \%)$ died before completion of the study, two in the $\mathrm{DMH}$ group $(\mathrm{C} ; 6.7 \%)$, and four in the $\mathrm{DMH}+$ ethanol group $(E ; 20.0 \%)$. In group $C$ one male rat died without the possibility of an early autopsy, and one female rat showed no tumors when the autopsy was performed. In group E, two male rats died due to an intestinal obstruction by a colon tumor in both cases; one male rat developed a colon tumor with metastases and digestive hemorrhage; and one female rat showed no tumors. These animals were therefore excluded from the analysis. The rats that completed the study showed no evidence of dehydration.

Alcohol consumption was similar in both ethanol-fed groups $(1.23 \pm 0.0074 \mathrm{~g} / \mathrm{kg}$ of body wt per day in group B compared to $1.23 \pm 0.0094$ in group $E ; p=0.82$ ), ethanol consumption was measured daily throughout the study.

No tumors were seen in the animals of DMH-free groups (A, B, and D). Tumors developed only in DMHtreated groups: twenty-five rats in the DMH group (28 rats) and sixteen rats in the $\mathrm{DMH}+$ ethanol group (16 rats). With respect to gender, there were fewer tumor-free animals amongst males (14.3\% in both groups) versus females $(78.6 \%$ in the $\mathrm{DMH}$ group, $\mathrm{p}=0.0006 ; 55.6 \%$ in the $\mathrm{DMH}+$ ethanol group, $\mathrm{p}=0.14$, Fisher's exact test) 
(Table I). When excluding tumor-free animals, no differences were observed in the mean number of tumors per rat (1.67 in the DMH group compared to 1.60 in the $\mathrm{DMH}+$ ethanol group). No hepatic metastases were recorded in either group.

Table I. Tumor incidence and distribution

\begin{tabular}{lcc}
\hline & DMH group & DMH + ethanol group \\
\hline Number of rats at sacrifice & $28(93.3 \%)$ & $16(80 \%)$ \\
$\quad$ Males: Females & $14: 14$ & $7: 9$ \\
Number of tumor-free rats & $13(46.4 \%)$ & $6(37.5 \%)$ \\
$\quad$ Males & $2 / 14(14.3 \%)$ & $1 / 7(14.3 \%)$ \\
$\quad$ Females & $11 / 14(78.6 \%)^{*}$ & $5 / 9(55.6 \%)$ \\
Total number of tumors & 25 & 16 \\
$\quad$ Males: Females & $22: 3$ & $12: 4$ \\
Mean number of tumors / rat $( \pm$ SD) & $1.67 \pm 1.23$ & $1.60 \pm 1.02$ \\
$\quad$ Males & $1.83 \pm 1.34$ & $2.00 \pm 0.89$ \\
Females & $1.00 \pm 0.00$ & $1.00 \pm 0.00$ \\
\hline
\end{tabular}

${ }^{*} \mathrm{p}=0.0006$ versus males in $\mathrm{DMH}$ group; SD: standard deviation; $\mathrm{DMH}$ : dimethylhydrazine. Data in parentheses reflect percentage of total.

No significant differences were found in tumor size (55.40 $\mathrm{mm}^{2}$ in the DMH group compared toh $45.87 \mathrm{~mm}^{2}$ in the DMH + ethanol group). In terms of macroscopic morphology, $80 \%$ of tumors had a polypoid aspect in the $\mathrm{DMH}$ group, versus $81.3 \%$ in the $\mathrm{DMH}+$ ethanol group. In relation to tumor location, $68 \%$ of tumors were located in the left colon in the DMH group, compared to $56.2 \%$ in the DMH + ethanol group (Table II).

Table II. Macroscopic characteristics of the tumors

\begin{tabular}{lcc}
\hline & $\begin{array}{c}\text { DMH group } \\
(\mathbf{n}=\mathbf{2 5})\end{array}$ & $\begin{array}{c}\text { DMH + ethanol group } \\
(\mathbf{n}=\mathbf{1 6})\end{array}$ \\
\hline Mean tumor size \pm SD) & $55.40 \pm 157.29$ & $45.87 \pm 53.13$ \\
$\quad$ Males & $59.45 \pm 167.40(n=22)$ & $39.08 \pm 49.69(\mathrm{n}=12)$ \\
$\quad$ Females & $25.67 \pm 33.65(n=3)$ & $66.25 \pm 65.76(n=4)$ \\
Macroscopic tumor findings & & \\
$\quad$ Polypoid & $20(80 \%)$ & $13(81.3 \%)$ \\
$\quad$ Normal mucosa & $2(8 \%)$ & $2(12.5 \%)$ \\
$\quad$ Other morphologies & $3(12 \%)$ & $1(6.2 \%)$ \\
Tumor distribution in colon & & \\
Right colon & $8(32 \%)$ & $7(43.8 \%)$ \\
Left colon & $17(68 \%)$ & $9(56.2 \%)$ \\
\hline
\end{tabular}

SD: standard deviation; DMH: dimethylhydrazine; $n$ : number of tumors. Data in parentheses reflect percentage of total. Tumor size is expressed as the greatest tumor area in squared millimeters.

Microscopic findings (Table III) revealed no differences for animals in the DMH group compared to those in the $\mathrm{DMH}+$ ethanol group in terms of number of adenocarcinomas and mucinous carcinomas (considering a mucinous component $>50 \%$ of tumor), or regarding extent of invasion or differentiation, or in tumor association with lymphoid tissue. However, DMH-treated rats in group $\mathrm{C}$ (DMH control group) had a significantly higher
Table III. Microscopic characteristics of the tumors

\begin{tabular}{lcc}
\hline & $\begin{array}{c}\text { DMH group } \\
(\mathbf{n}=25)\end{array}$ & $\begin{array}{c}\text { DMH + ethanol group } \\
(\mathbf{n}=16)\end{array}$ \\
\hline Adenocarcinomas & $16(64 \%)$ & $8(50 \%)$ \\
Mucinous carcinomas & $9(36 \%)$ & $8(50 \%)$ \\
Degree of differentiation & & \\
$\quad$ High & $5(20 \%)$ & $4(25 \%)$ \\
$\quad$ Moderate & $8(32 \%)$ & $5(31.3 \%)$ \\
$\quad$ Poor & $12(48 \%)$ & $7(43.7 \%)$ \\
Extent of invasion & & \\
$\quad$ In situ carcinoma & $5(20 \%)$ & $4(25 \%)$ \\
$\quad$ Peritoneal involvement & $1(4 \%)$ & $1(6.3 \%)$ \\
$\quad$ Other & $19(76 \%)$ & $11(68.7 \%)$ \\
Associated lymphoid tissue & $7(28 \%)$ & $5(31.3 \%)$ \\
\hline
\end{tabular}

DMH: dimethylhydrazine; $\mathrm{n}$ : number of tumors. Data in parentheses reflect percentage of total.

number of mucinous carcinomas in the right colon $(75 \%)$ compared to those found in the left colon $(17.6 \% ; \mathrm{p}=$ $0.006)$; in the $\mathrm{DMH}+$ ethanol group this trend was also observed $(71.4 \%$ in the right colon versus $33.3 \%$ in the left colon, $\mathrm{p}=0.31$ using Fisher's exact test) (Table IV).

Two small-bowel tumors were also found: one in the $\mathrm{DMH}$ group and one in the $\mathrm{DMH}+$ ethanol group. A tumor of the ear was found in the DMH group.

Table IV. Tumor classification in relation to location

\begin{tabular}{lcc}
\hline & $\begin{array}{c}\text { DMH group } \\
(\mathbf{n}=\mathbf{2 5})\end{array}$ & $\begin{array}{c}\text { DMH + ethanol group } \\
(\mathbf{n}=\mathbf{1 6})\end{array}$ \\
\hline Right colon & 8 & 7 \\
Tumor size $( \pm$ SD) & $129.50 \pm 272.99$ & $45.43 \pm 57.42$ \\
Adenocarcinomas & $2(25 \%)$ & $2(28.6 \%)$ \\
Mucinous carcinomas & $6(75 \%)$ & $5(71.4 \%)$ \\
Left colon & 17 & 9 \\
Tumor size $( \pm$ SD) & $20.53 \pm 21.62$ & $46.22 \pm 53.11$ \\
Adenocarcinomas & $14(82.4 \%)$ & $6(66.7 \%)$ \\
Mucinous carcinomas & $3(17.6 \%)$ & $3(33.3 \%)$ \\
\hline
\end{tabular}

${ }^{*} \mathrm{p}=0.006$ versus mucinous carcinomas of left colon in DMH group; SD: standard deviation; $\mathrm{DMH}$ : dimethylhydrazine; n: number of tumors. Data in parentheses reflect percentage of total. Tumor size is expressed as the greatest tumor area in squared millimeters.

\section{DISCUSSION}

Ethanol consumption is described as a risk factor for colorectal cancer, a hypothesis supported by both clinical (5-8) and experimental trials in rats $(16,17)$.

To facilitate colon cancer studies with controlled variables, chemically induced carcinogenesis with 1,2 dimethylhydrazine $(\mathrm{DMH})$ in the rat has proven to be a valuable experimental model for more than three decades (18-20).

In retrospective studies, an increased risk for colon cancer has been described for women at a dose of $63 \mathrm{~g}$ per day (5). Other authors (9) found no relationship at 30 $\mathrm{g}$ per day. Following these clinical findings, our rats received $1.23 \mathrm{~g} / \mathrm{kg}$ of ethanol daily for 24 weeks, which is a 
common but risky consumption in humans. We present an original work where a common alcohol consumption, at a fixed dose and duration, is used to prove the absence of influence in colorectal carcinogenesis.

Under these conditions and with the amount of ethanol described, rats showed no natural aversion to alcohol. Thus, we did not expect to find significant differences in ethanol consumption between the $\mathrm{DMH}+$ ethanol group and the non-ethanol control group.

Depending on experimental conditions, chemically induced colorectal carcinogenesis is controversial: when $\mathrm{DMH}$ is given in the presence of alcohol carcinogenesis is inhibited, whereas in the absence of alcohol carcinogenesis is stimulated due to an ethanol-associated microsomal cytochrome P450 induction (31). Moreover, when using a primary carcinogen instead of a procarcinogen, alcohol stimulates carcinogenesis (32). Based on the results of these studies the administration of alcohol could have decreased DMH-induced carcinogenesis; however, in our study no significant differences were found in colorectal carcinogenesis when comparing the DMH group to the $\mathrm{DMH}+$ ethanol group.

The dose of ethanol administered did not significantly modify the number of DMH-induced tumor-free rats, nor did it modify the number of tumors per rat either. Some authors (32) have described no significant differences in tumor size or in tumor histology due to an alcohol effect, as found in our study. Nevertheless, these authors have shown an increased number of tumors in the rectum, but this was not seen in our rats. We found that ethanol consumption did not alter the number or size of DMH-induced tumors, or their distribution throughout the colorectal tract, this being similar to findings by other authors in DMH models (33).

In human studies, patients with colorectal carcinoma who use alcohol seem to have higher cancer-related mortality rates due to a greater development of liver metastases (34). No support for these findings was found in our study.

In vitro studies (15) have described that ethanol consumption may enhance the aggressiveness of colorectal tumors. These authors defined it as increased tumoral cell proliferation rate, decreased tumoral differentiation, and diminished cellular adhesion. Although some studies in mice (35) report that ethanol intake promotes changes in the mucosal lymphoid tissue, and that this may explain the cocarcinogenesis mechanism (28), this was not observed in our rats. Our results show no significant differences in the anatomopathologic characteristics of tumors in DMH-induced rats as a result of the effect of alcohol. Thus, this aggressive behavior was not detected in tumors found in our animals.

In epidemiologic studies, the mechanism by which alcohol intake may modify carcinogenesis seems to be timeand dose-response related $(4,5,36)$, although some studies are far from unanimous on this issue (37). Taking these studies together, data suggest that the longer the ethanol intake, the lower the dose per day needed. Following this hypothesis, the reason for our findings -which suggest that ethanol would not act in the pathogenic mechanism of colon cancer- may lie in a timing effect variability; it seems that this relatively low dose is not dangerous enough to modify colorectal carcinogenesis, but a dynamic model of concomitant administration of alcohol and procarcinogen, as used by us, is a controversial design for studying colorectal carcinogenesis as induced by ethanol.

Certain authors have shown a spontaneous colonic carcinogenesis rate of less than 2-3 rats per 100.000 animals (38). In our DMH-free rats, and as expected, no tumors developed.

Tumors in the proximal and distal colon and rectum must be considered to have some differences regarding risk factors, etiology, histological appearance, and growth characteristics of tumors; this is based on epidemiologic studies (9) and experimental studies in rats (39); thus responses of the epithelium may differ at different locations in DMH-induced rats (16).

It is important to note that tumors in our rats were classified according to the criteria described above. According to these, a mucinous adenocarcinoma is considered a poorly differentiated tumor (29). A correlation was found between tumors located in the right colon and the poor grade of differentiation, both in experimental studies (40) and literature reviews (41). In our study, we have been able to demostrate the existence of an increased number of mucinous carcinomas in the right colon compared to the left colon in rats included in the DMH group, although a trend towards this behaviour has been seemingly shown in rats in the $\mathrm{DMH}+$ ethanol group (probably because the number of tumors was not significant enough). Our data are in conflict with results from other studies $(31,42)$, which have reported that the number of right colonic tumors was inversely correlated with alcohol consumption in a dynamic model of carcinogenesis. We therefore think that the dose of alcohol in our study was relatively low to show any inhibitory effect on right colonic tumors; right tumors therefore showed their own and worse behavior when compared to left tumors, as suggested by some authors $(40,41)$. Our results are not comparable to those by authors $(25,43)$ due to the different histologic criteria used $(29,44)$.

Firstly we conclude that an oral ethanol supplement at a dose of $1.23 \mathrm{~g} / \mathrm{kg}$ of body wt per day for 24 weeks does not modify colon cancer in a dynamic model of carcinogenesis induced by DMH in Sprague-Dawley rats; and secondly that a different histologic behavior exists in tumors located in the right colon as compared to tumors located in the left colon due to the effect of ethanol.

\section{ACKNOWLEDGEMENTS}

The authors wish to thank Mr. Manuel Santiago for his technical support and animal care. This research work has been supported by University of Lleida, and a grant “Research Help FIS number 89/0612". 


\section{REFERENCES}

1. Greenwald P. Colon cancer overview. Cancer 1992; 70: 1206-15.

2. Trock B, Lanza E, Greenwald P. Dietary fiber, vegetables and colon cancer: Critical review and meta-analyses of the epidemiologic evidence. J Natl Cancer Inst 1990; 82: 650-61.

3. Vargas PA, Alberts DS. Primary prevention of colorectal cancer through dietary modifications. Cancer 1992; 70: 1229-35.

4. Kuhne GA, Vitetta, L. Alcohol consumption and the etiology of colorectal cancer: a review of the scientific evidence from 1957 to 1991. Nutr Cancer 1992; 18: 97-111.

5. Barra S, Negri E, Franceschi S, Guarneri S, La Vecchia C. Alcohol and colorectal cancer: A case-control study from northern Italy. Cancer Causes Control 1992; 3: 153-9.

6. Glynn SA, Albanes D, Pietinen P, Brown CC. Rautalahti M, Tangrea $\mathrm{JA}$, et al. Alcohol consumption and risk of colorectal cancer in a cohort of Finnish men. Cancer Causes Control 1996; 7: 214-23.

7. Murata M, Takayama K, Choi BC, Pak AW. A nested case-control study on alcohol drinking, tobacco smoking, and cancer. Cancer Detect Prev 1996; 20: 557-65.

8. Yamada K, Araki S, Tamura M, Sakai I, Takahashi Y, Kashihara, et al. Case-control study of colorectal carcinoma in situ and cancer in relation to cigarette smoking and alcohol use (Japan). Cancer Causes Control 1997; $18:$ 780-5

9. Gerhardsson de Verdier M, Romelsjo A, Lundberg M. Alcohol and cancer of the colon and rectum. Eur J Cancer Prev 1993; 2: 401-8.

10. Tavani A, Ferraroni M, Mezzetti M, Franceschi S, Lo Re A, La Vecchia C. Alcohol intake and risk of cancers of the colon and rectum. Nutr Cancer 1998; 30: 213-9.

11. Kono S, Ikeda N, Yanai F, Shinchi K, Imanishi K. Alcoholic beverages and adenomatous polyps of the sigmoid colon: A study of male self-defence officials in Japan. Int J Epidemiol 1990; 19: 848-52.

12. Weisburger JH. Causes, relevant mechanisms and prevention of large bowel cancer. Semin Oncol 1991; 18: 316-36.

13. Goldbohm RA, Van den Brandt PA, Van't Veer P, Dorant E, Stumans F, Hermus RJ. Prospective study on alcohol consumption and the risk of cancer of the colon and rectum in the Netherlands. Cancer Causes Control 1994; 5: 95-104.

14. Nagata C, Shimizu H, Kametani M, Takayama N, Ohnuma T, Matsushita S. Cigarette's smoking, alcohol use, and colorectal adenoma in Japanese men and women. Dis Colon Rectum 1999; 42: 337-42.

15. KoivistoT, Salaspuro M. Acetaldehyde alters proliferation, differentiation, and adhesion properties of human colon adenocarcinoma cell line Caco-2. Carcinogenesis 1998; 19: 2031-6.

16. Seitz HK, Czygan P, Simanowski UA, Waldherr R, Veith S, Raedsch $\mathrm{R}$, et al. Stimulation of chemically induced rectal carcinogenesis by chronic ethanol ingestion. Alcohol 1985; 20: 427-33.

17. Simanowski UA, Stickel F, Maier H, Gartner U, Seitz HK. Effects of alcohol on gastrointestinal cell regeneration as a possible mechanism in alcohol-associated carcinogenesis. Alcohol 1995; 12: 111-5.

18. Banerjee A, Quirke P. Experimental models of colorectal cancer. Dis Colon Rectum 1998; 41: 490-505.

19. Barkla DH, Tutton PJ. Ultrastructure of 1,2-dimethylhydrazine-induced adenocarcinomas in rat colon. J Natl Cancer Inst 1997; 61: 1291-9.

20. Druckrey H, Preussman R, Matzkies F. Selektive Erzeugung von Darmkaebs bei Ratten durch 1,2-Dimethylhydrazin. Naturwissenschaften 58:285-286; 1967. In: Barkla DH, Tutton PJ. Ultrastructure of 1,2-dimethylhydrazine-induced adenocarcinomas in rat colon. J Natl Cancer Inst 1988; 61: 1291-9.

21. Hupp T, Buhr HJ, Ivancovic S, Beck N. Tierexperimentelle Untersuchungen zur karzinogeninduzierten Tumorbildung an Kolotomien in Abhängigkeit von Nahtmaterialien (Influence of suture material on experimental colonic carcinogenesis in rats). Langenbecks Arch Chir 1992; 377: 9-13

22. Viñas Salas J, Biendicho Palau P, Piñol Felis C, Miguelsanz García S Pérez Holanda S. Calcium inhibits colon carcinogenesis in an experimental model in the rat. Eur J Cancer 1998; 34: 1941-5.

23. Buenestado García J, Reñé Espinet JM, Piñol Felis C, Viñas Salas J. Modelo experimental de cáncer colorrectal. Rev Esp Enferm Dig 2002; 94: 367
24. Buenestado García J, Piñol Felis C, Reñé Espinet JM, Pérez-Holanda $\mathrm{S}$, Viñas Salas J. Silk suture promotes colon cancer in an experimental carcinogenic model. Dig Liver Dis 2002; 34: 609-10.

25. Noguera Aguilar JF, Tortajada Collado C, Moron Canis JM, Plaza Martínez A, Amengual Antich I, Pujol Tugores JJ. Modelo experimental para el estudio de la recidiva locorregional del cáncer colorrectal. Rev Esp Enferm Dig 2002; 94: 131-8.

26. Seitz HK, Simanowski UA. Alcohol and carcinogenesis. Am Rev Nutr 1988; 8: 99-119.

27. Glauert HP, Bennink MR. Influence of diet or intrarectal bile acid injections on colon epithelial cell proliferation in rats previously injected with 1,2-dimethylhydrazine. J Nutr 1983; 113: 475-82.

28. Hardman WE, Cameron IL. Colonic crypts located over lymphoid nodules of 1,2-dimethylhydrazine-treated rats are hyperplastic and at high risk of forming adenocarcinomas. Carcinogenesis 1994; 15 : 2353-61.

29. Grau de Castro JJ, Piqué Badía JM. Cáncer colorrectal. En: Monografías clínicas en oncología. Barcelona: Ed. Doyma SA, 1990; 8: 63-75.

30. Lev R. Adenomatous polyps of the colon: Pathological and clinical features. New York: Springer-Verlach Inc., 1990. p. 1-2, 1-18.

31. Seitz HK, Czygan P, Waldherr R, Veith S, Raedsch R, Kässmodel H, et al. Enhacement of 1,2-Dimethylhydrazine-induced rectal carcinogenesis following chronic ethanol consumption in the rat. Gastroenterology 1984; 86: 886-91.

32. Seitz HK, Simanowski UA, Garzon FT, Rideout JM, Peters TJ, Koch A, et al. Possible role of acetaldehyde in ethanol-related rectal cocarcinogenesis in the rat. Gastroenterology 1990; 98: 406-13.

33. McGarrity TJ, Peiffer LP, Colony PC, Pegg AE. The effect of chronic ethanol administration on polyamine content during dimethylhydrazine induced colorectal carcinogenesis in the rat. Carcinogenesis 1988; 9: 2093-8.

34. Maeda M, Nagawa H, Maeda T, Koike H, Kasai H. Alcohol consumption enhances liver metastasis in colorectal carcinoma patients. Cancer 1998; 83: 1483-8.

35. López MC, Watzl B, Hebert AR, Murphy L, Huang DS, Watson RR. Ethanol-induced changes in the intestinal mucosa-associated immune system of young and mature mice. Alcohol 1993; 10: 555-7.

36. Newcomb PA, Storer BE, Marcus PM. Cancer of the large bowel in women in relation to alcohol consumption: A case-control study in Wisconsin (United States). Cancer Causes Control 1993; 4 : 405-11.

37. Riboli E, Cornee J, Macquart-Moulin G, Kaaks R, Casagrande C, Guyader M. Cancer and polyps of the colo-rectum and lifetime consumption of beer and other alcoholic beverages. Am J Epidemiol 1991; 134: 157-66.

38. Winkler R, Pfeiffer M, Ayisi K, Dörner A. Spontaneous colostomy cancer in rat: a handly model of colonic carcinogenesis. En: Malt RA, Williamson RCN. Colonic carcinogenesis. Boston: MTP Press Limited, Harvard Medical School, 1982. p. 245-52.

39. McGarrity TJ, Peiffer LP, Colony PC. Cellular proliferation in proximal and distal rat colon during 1,2.dimethylhydrazine-induced carcinogenesis. Gastroenterology 1988; 95: 343-8.

40. Park HS, Goodlad RA, Wright NA. The incidence of aberrant crypt foci and colonic carcinoma in dimethylhydrazine-treated rats varies in a site-specific manner and depends on tumor histology. Cancer Res 1997; 57: 4507-10.

41. Klurfeld DM. Dietary fiber-mediated mechanisms in carcinogenesis. Cancer Res 1992; 52 (Supl. 7): 2055s-2059s.

42. Hamilton SR, Sohn OS, Fiala ES. Effects of timing and quality of chronic dietary ethanol consumption on azoxymethane-induced colonic carcinogenesis and azoxymethane metabolism in Fisher 344 rats. Cancer Res 1987; 47: 4305-11.

43. Noguera Aguilar JF, Zurita Romero M, Tortajada Collado C, Amengual Antich I, Soro Gosálvez JA, Rial Planas R. Perianastomotic colonic tumors after inclusion of titanium or Lactomer in the anastomotic suture line. An experimental study in rats. Rev Esp Enferm Dig 2000; 92: 36-43.

44. Pérez-Holanda S. Réplica "Relación entre el grado de diferenciación celular del cáncer colorrectal y su distribución topográfica”. Rev Esp Enferm Dig 2002, 94: 568. 


\title{
Efecto de la ingesta de etanol en un modelo experimental de cáncer de colon
}

\author{
S. Pérez-Holanda, L. Rodrigo' ${ }^{1}$ J. Viñas-Salas ${ }^{2}$ y C. Piñol-Felis ${ }^{2}$ \\ Servicio de Cirugía. Hospital Grande Covián. Arriondas. Asturias. 'Departamento de Medicina. Facultad de Medicina. \\ Universidad de Oviedo. Asturias. ${ }^{2}$ Departamento de Medicina y Departamento de Cirugía. Facultad de Medicina. \\ Hospital Universitario “Arnau de Vilanova”. Universidad de Lleida
}

\section{RESUMEN}

Objetivos: el presente trabajo experimental fue diseñado para examinar el efecto de la adición de un suplemento de etanol oral en ratas, en la aparición y desarrollo de la carcinogénesis colónica.

Material y métodos: se utilizaron un total de ciento diez ratas de la raza "Sprague-Dawley" de 10 semanas de vida, que se dividieron en 5 grupos: grupo A (20 ratas), sin tratamiento. Grupo $\mathrm{B}$ (20 ratas), con adición de etanol a la dosis de $1,23 \mathrm{~g} / \mathrm{kg}$ peso al día, añadido al agua de bebida, durante 24 semanas. Grupo C (30 ratas), tratadas con 18 dosis semanales de dimetilhidracina (DMH) a la dosis de $21 \mathrm{mg} / \mathrm{kg}$ peso, cada una, desde la semana 10 de vida. Grupo D (20 ratas), tratadas únicamente con solución de ácido etilen-diamino-tetracético (EDTA), durante 18 semanas. Grupo E (20 ratas), tratadas con etanol a la misma dosis que las ratas del grupo B y las mismas inyecciones de $\mathrm{DMH}$ que las ratas del grupo $\mathrm{C}$, administradas ambas de forma concomitante, desde la semana 10 de vida. Todas las ratas fueron sacrificadas entre las 25-27 semanas, del comienzo del estudio. Se estudió la incidencia de tumores colorrectales y su localización, así como los hallazgos anátomo-patológicos comparados entre grupos.

Resultados: no se observaron diferencias significativas, ni en el número de ratas que desarrollaron tumores de colon, ni en el número de animales libres de tumor, ni en el número de tumores por rata, ni en los hallazgos macro-microscópicos de los tumores entre los animales del grupo C, con respecto a los del grupo E.

Conclusiones: la adición de un suplemento de etanol a la dieta, en la dosis y tiempo establecidos, no modificó la producción de carcinogénesis colónica en ratas, usando un modelo dinámico de administración concomitante de inducción tumoral con $\mathrm{DMH}$.

Palabras clave: Alcohol. Cáncer. Carcinogénesis. Colon. Dimetilhidracina. Etanol. Neoplasia. Tumores.

\section{INTRODUCCIÓN}

El cáncer colorrectal (CCR) es un tumor frecuente, con una elevada mortalidad en los países occidentales (1), en los que la ingesta de alcohol es un hábito común. En un metanálisis realizado sobre su posible etiopatogenia se ha demostrado de forma convincente que los factores ambientales juegan un papel destacado en su inducción (2). De hecho, la tasa de incidencia podría verse reducida en un $30-35 \%$ aproximadamente, mediante la modificación de los hábitos alimentarios (3).
En un relevante trabajo basado en la evidencia epidemiológica y publicado en 1992 (4) se encontró una asociación entre el consumo de alcohol y el CCR. Más recientemente, mientras que algunos estudios clínicos defienden que la ingesta de etanol incrementa el riesgo de CCR (5-8), otros autores no observan dicha relación $(9,10)$ e incluso otros investigadores defienden la teoría de que únicamente habría una relación con el desarrollo de adenomas, pero no con el CCR (11). Para estudiar la influencia de los diferentes factores etiológicos ambientales sobre el cáncer de colon en el hombre, los estudios prospectivos a largo plazo son difíciles de llevar a cabo (12). No obstante, muestran unos resultados contradictorios, defendiendo la asociación con cáncer en un caso (13) o mostrando una relación con la producción de adenomas únicamente en otro (14). Por otro lado, estudios experimentales han mostrado un mayor riesgo de CCR por efecto del alcohol tanto in vitro (15) como en modelos con roedores $(16,17)$.

La inducción de cáncer colorrectal con 1,2 dimetilhidracina (DMH) en ratas es un modelo experimental válido actualmente y superponible al humano debido a que los tumores inducidos con DMH lo semejan tanto en sus características macro-microscópicas como en su comportamiento clínico (18-20).

El objetivo del presente estudio es investigar el efecto del consumo de etanol en ratas sometidas a la inducción tumoral colónica del DMH, dentro de un modelo dinámico (de administración concomitante) de ambas sustancias.

\section{MATERIAL Y MÉTODOS}

Se estableció un número de 20 ratas por grupo en base a una inducción tumoral a la dosis y tiempo establecidos por la DMH del $76-90 \%$ de las ratas $(21,22)$; para una tasa de tumores en las ratas inducidas por DMH de 1,87; y una mortalidad variable y elevada según estudios previos en esta misma línea de investigación $(23,24)$. Dicho número de ratas asignadas a cada grupo coincidió con otros autores consultados (25). 
Ciento diez ratas "Sprague-Dawley" de 10 semanas de vida (Lab. Letica ${ }^{\circledR}$, Barcelona, España), 55 machos y 55 hembras de la misma línea genética, fueron distribuidas en cinco grupos con igual número de machos que de hembras en cada uno. Ninguna de las 20 ratas del grupo A (grupo control) recibió tratamiento alguno. Las 20 ratas del grupo B (grupo control de etanol) recibieron etanol a 1,23 $\mathrm{g} / \mathrm{kg}$ peso al día, añadido al agua corriente desde el principio del estudio hasta el sacrificio de las ratas. Se tomaron 30 ratas en el grupo $\mathrm{C}$ debido a la alta mortalidad obtenida en el grupo DMH en estudios previos (2224). Dichas 30 ratas del grupo C (grupo control de DMH) recibieron 18 inyecciones subcutáneas (s.c.) semanales de $21 \mathrm{mg} / \mathrm{kg}$ peso de 1,2 dimetilhidracina (DMH; Fluka Chemica A.G., Sigma Co. ${ }^{\circledR}$, St. Louis, Missouri, U.S.A.) desde la semana 10 de vida y de forma continuada. La solución inyectable de la DMH se preparó semanalmente, como en dichos estudios previos diluyendo $400 \mathrm{mg}$ de DMH en agua destilada que contenía $37 \mathrm{mg}$ de ácido etilenodiaminotetraacético (EDTA; Farmitalia Carlo Erba S.P.A. ${ }^{\circledR}$, Milano, Italy) como agente estabilizador y ajustándose a un pH de 6,5 mediante hidróxido sódico 0,1 M (22). Las inyecciones se aplicaron en la región lumbar de la rata. Las 20 ratas del grupo D (grupo control de EDTA) recibieron el mismo volumen de la solución de EDTA que el grupo $\mathrm{C}$, mezclada con agua destilada únicamente y sin DMH. Las 20 ratas del grupo E (grupo DMH + etanol) fueron tratadas con 18 inyecciones sc subcutáneas de $21 \mathrm{mg} / \mathrm{kg}$ peso de DMH, y 1,23 g/kg peso al día de etanol añadido al agua corriente, comenzando a la vez que la primera inyección de $\mathrm{DMH}$ en la semana 10 de vida y hasta el final del estudio. La cantidad ingerida de etanol se cuantificó en función de la cantidad de agua corriente consumida por las ratas.

La alimentación de todas las ratas del estudio fue estándar (Dieta ITM-R20, Lab. Letica ${ }^{\circledR}$, Barcelona, España) la cual contiene un $3 \%$ de grasa y un $5 \%$ de fibra. La cantidad de alimento consumido por las ratas de los grupos tratados se controló a lo largo del estudio. El 50\% de los animales de cada grupo eran pesados semanalmente hasta el momento del sacrificio. Además, se controló estrictamente la cantidad de etanol consumido por las ratas para evitar la deshidratación secundaria a la administración de etanol junto con el agua corriente observada por algunos autores (26). La habitación del estabulario se mantuvo a una temperatura y una humedad constantes, donde las ratas fueron sometidas a un ciclo circadiano de luz-oscuridad de 12 horas, como recomiendan diversos autores $(27,28)$, y se separaron en jaulas con un máximo de tres animales por jaula, para evitar la autofagia y controlar el consumo oral de alcohol, como en estudios previos (22-24).

Se siguieron las recomendaciones para el trato de animales de experimentación del Comité Europeo de Ética (Directiva de la C. E. E. número 1986/609) a lo largo de todo el estudio.

Las ratas que sobrevivieron fueron sacrificadas entre las semanas 25 y 27 del estudio mediante instilación in- traperitoneal de una dosis letal de hidrato de cloral al $4,5 \%$, el cual induce primeramente un sueño profundo y posteriomente provoca la muerte del animal. Para evitar variaciones de los resultados, un número fijo e igual de ratas de cada grupo se sacrificaron en cada una de las semanas que duró el sacrificio (22).

En el momento de la autopsia, se examinaron las cavidades torácica y abdominal. Se extrajeron el colon y el recto, se abrieron a lo largo del borde antimesentérico y se lavó cuidadosamente la mucosa con agua corriente. Posteriomente se palpaba el tracto intestinal por completo para hallar tumores, adherencias u otras alteraciones. Se hizo un registro con el número de tumores, su localización y su tamaño. Posteriormente se tomaron muestras para el estudio histológico de los tumores así como de segmentos de la mucosa normal, tanto a nivel del ciego y colon ascendente (colon derecho) como del colon transverso, descendente y recto (colon izquierdo). Estas muestras se fijaron en formol al $10 \%$, se incluyeron en parafina, se cortaron con el microtomo y se tiñeron mediante la tinción hematoxilina-eosina. Las lesiones de la mucosa colónica se clasificaron según los criterios de Grau de Castro-Piqué Badía (29) y Lev (30). Los tumores obtenidos se clasificaron en función de su grado de invasión parietal, de su diferenciación, de su estirpe histológica (definiendo al carcinoma mucinoso cuando su componente de mucina es superior al $50 \%$ ), de su asociación a una placa linfoide, de su tamaño y de su aspecto macroscópico. Por otro lado se registraron los tumores de intestino delgado aparecidos así como otros hallazgos extraintestinales.

Se utilizó el test de Chi cuadrado para comparar entre los grupos de DMH (C) y DMH + etanol (E) la incidencia de tumores, los hallazgos anátomopatológicos, el número total de tumores colorrectales, el número de tumores desarrollados en el colon derecho y en el colon izquierdo, el tamaño medio de los tumores y la asociación tumoral con una placa linfoide. En los sucesos en que las condiciones para la aplicación del test de Chi cuadrado no se cumplieron, se utilizó el test de la corrección exacta de Fisher. Las diferencias entre ambos grupos fueron significativas cuando el valor de p resultó igual o menor que 0,05 . Los resultados se presentan como media \pm desviación estándar (SD).

\section{RESULTADOS}

Seis ratas $(5,5 \%)$ murieron antes de completar el estudio, 2 del grupo DMH $(\mathrm{C} ; 6,7 \%)$ y 4 del grupo $\mathrm{DMH}+\mathrm{etanol}(\mathrm{E} ; 20,0 \%)$. En el grupo $\mathrm{C}$, falleció precozmente 1 rata macho a la que se realizó la autopsia muy tardíamente y no se pudo identificar la causa de muerte; y una rata hembra en la que no se identificó ningún tumor en la autopsia. En el grupo E, la mortalidad observada se debió en dos ratas machos a sendos tumores oclusivos, y la tercera rata macho falleció por hemorragia digestiva 
baja secundaria a un tumor colónico que la autopsia reveló también metástasis hepáticas; así como una rata hembra que no presentó tumor alguno. Estos animales se excluyeron del análisis. En el resto de las ratas que completaron el estudio no se apreciaron signos de deshidratación.

No se observaron diferencias significativas en la media de consumo de alcohol entre las ratas de los dos grupos que lo consumieron $(1,23 \pm 0,0074 \mathrm{~g} / \mathrm{kg}$ peso al día en el grupo B y 1,23 $\pm 0,0094$ en el grupo $E ; p=0,82$ ), midiendo el consumo de alcohol diariamente durante todo el estudio.

En los grupos sin DMH (grupo A, B y D) no se encontraron tumores. Únicamente aparecieron tumores colónicos en las ratas tratadas con $\mathrm{DMH}, 25$ en el grupo $\mathrm{DMH}$ (28 ratas) y 16 en el grupo DMH + etanol (16 ratas). Hubo un menor número de animales machos libres de tumor (14,3\% en ambos grupos) que de hembras libres de tumor $(78,6 \%$ en el grupo DMH, $\mathrm{p}=0,0006 ; 55,6 \%$ en el grupo DMH+etanol, $\mathrm{p}=0,14$ con la corrección del test de Fisher) (Tabla I). Excluyendo los animales libres de tumor, no se observaron diferencias significativas en el promedio de tumores por rata hallados entre los dos grupos inducidos con DMH (1,67 en el grupo DMH y 1,60 en el grupo $\mathrm{DMH}+$ etanol). No se registró ninguna metástasis hepática en estos grupos.

Tabla I. Incidencia tumoral y distribución

\begin{tabular}{ccc}
\hline & Grupo DMH (C) & Grupo DMH+etanol (E) \\
\hline Número de ratas al sacrificio & $28(93,3 \%)$ & $16(80 \%)$ \\
Machos: hembras & $14: 14$ & $7: 9$ \\
Número de ratas libres de tumor & $13(46,4 \%)$ & $6(37,5 \%)$ \\
Machos & $2 / 14(14,3 \%)$ & $1 / 7(14,3 \%)$ \\
Hembras & $11 / 14(78,6 \%)$ & $5 / 9(55,6 \%)$ \\
Número total de tumores & 25 & 16 \\
Machos: hembras & $22: 3$ & $12: 4$ \\
Promedio de tumores / rata $( \pm$ SD) & $1,67 \pm 1,23$ & $1,60 \pm 1.02$ \\
Machos & $1,83 \pm 1,34$ & $2,00 \pm 0,89$ \\
Hembras & $1,00 \pm 0,00$ & $1,00 \pm 0,00$ \\
\hline
\end{tabular}

$\mathrm{p}=0,0006$ (hembras frente a machos en grupo DMH); SD: desviación estándar. $\mathrm{DMH}$ : dimetilhidracina. Los datos entre paréntesis reflejan porcentajes del total.

En cuanto al tamaño tumoral, no se apreciaron diferencias significativas $\left(55,4 \mathrm{~mm}^{2}\right.$ en el grupo $\mathrm{C}$ y de 45,8 $\mathrm{mm}^{2}$ en el grupo E). Tampoco en la morfología macroscópica de los tumores (con un $80 \%$ de los mismos de características polipoideas en el grupo $\mathrm{C}$ y $81,3 \%$ en el grupo E), ni en su localización (con un $68 \%$ de los mismos en el colon izquierdo en el grupo $\mathrm{C}$ y un $56,2 \%$ en el grupo E) (Tabla II).

En cuanto a las características microscópicas de los tumores (Tabla III), no se observaron diferencias significativas entre las ratas de los grupos $\mathrm{C}$ y E, respecto al número de adenocarcinomas y carcinomas mucinosos (considerando un componente mucinoso $>50 \%$ del adenocarcinoma), en el grado de diferenciación tumoral, en
Tabla II. Características macroscópicas de los tumores

\begin{tabular}{lcc}
\hline & $\begin{array}{c}\text { Grupo DMH (C) } \\
(\mathbf{n}=\mathbf{2 5})\end{array}$ & $\begin{array}{c}\text { Grupo DMH+etanol (E) } \\
(\mathrm{n}=16)\end{array}$ \\
\hline Promedio tamaño tumoral $( \pm$ SD) & $55,40 \pm 157,29$ & $45,87 \pm 53,13$ \\
$\quad$ Machos & $59,45 \pm 167,40(n=22)$ & $39,08 \pm 49,69(n=12)$ \\
Hembras & $25,67 \pm 33,65(n=3)$ & $66,25 \pm 65,76(n=4)$ \\
Hallazgos macroscópicos tumorales & & \\
Polipoideo & $20(80 \%)$ & $13(81,3 \%)$ \\
Mucosa normal & $2(8 \%)$ & $2(12,5 \%)$ \\
Otras morfologías & $3(12 \%)$ & $1(6,2 \%)$ \\
Dsitribución tumoral en el colon & & \\
Colon derecho & $8(32 \%)$ & $7(43,8 \%)$ \\
Colon izquierdo & $17(68 \%)$ & $9(56,2 \%)$ \\
\hline SD: desviación estánar:
\end{tabular}

SD: desviación estándar: DMH: dimetilhidracina; $\mathrm{n}$ : número de tumores. Los datos entre paréntesis reflejan porcentajes del total. El tamaño tumoral se expresa como la mayor superficie tumoral medida en milímetros cuadrados.

Tabla III. Características microscópicas de los tumores

\begin{tabular}{lcc}
\hline & $\begin{array}{c}\text { Grupo DMH (C) } \\
(\mathbf{n}=25)\end{array}$ & $\begin{array}{c}\text { Grupo DMH+etanol (E) } \\
(\mathbf{n}=16)\end{array}$ \\
\hline Adenocarcinomas & $16(64 \%)$ & $8(50 \%)$ \\
Carcinomas mucinosos & $9(36 \%)$ & $8(50 \%)$ \\
Grado de diferenciación & & \\
$\quad$ Bien & $5(20 \%)$ & $4(25 \%)$ \\
$\quad$ Moderado & $8(32 \%)$ & $5(31,3 \%)$ \\
$\quad$ Pobre & $12(48 \%)$ & $7(43,7 \%)$ \\
Grado de invasión & & \\
$\quad$ Carcinoma in situ & $5(20 \%)$ & $4(25 \%)$ \\
$\quad$ Afectación del peritoneo & $1(4 \%)$ & $1(6,3 \%)$ \\
$\quad$ Otros & $19(76 \%)$ & $11(68,7 \%)$ \\
Tejido linfoide asociado & $7(28 \%)$ & $5(31,3 \%)$ \\
\hline
\end{tabular}

DMH: dimetilhidracina; $\mathrm{n}$ : número de tumores. Los datos entre paréntesis reflejan porcentajes del total.

el grado de invasión parietal o en la asociación con tejido linfoide. Sin embargo, las ratas del grupo C (grupo control de $\mathrm{DMH}$ ) presentaron un mayor número de carcinomas mucinosos en el colon derecho $(75 \%)$ que en el izquierdo $(17,6 \%)(\mathrm{p}=0,006)$. Esta tendencia también se observó en la localización de los tumores de las ratas del grupo E $(71,4 \%)$ en el colon derecho y $(33,3 \%)$ en el colon izquierdo ( $\mathrm{p}=0,31$, aplicando el test de corrección de Fisher) (Tabla IV).

Tabla IV. Clasificación tumoral en función de la localización

\begin{tabular}{ccc}
\hline & $\begin{array}{c}\text { Grupo DMH ( C) } \\
(\mathbf{n}=\mathbf{2 5})\end{array}$ & $\begin{array}{c}\text { Grupo DMH+etanol (E) } \\
(\mathbf{n}=\mathbf{1 6})\end{array}$ \\
\hline Colon derecho & 8 & 7 \\
Tamaño tumoral ( \pm SD) & $129.50 \pm 272.99$ & $45.43 \pm 57.42$ \\
Adenocarcinomas & $2(25 \%)$ & $2(28.6 \%)$ \\
Carcinomas mucinosos & $6(75 \%)^{*}$ & $5(71.4 \%)$ \\
Colon izquierdo & 17 & 9 \\
Tamaño tumoral $( \pm$ SD) & $20.53 \pm 21.62$ & $46.22 \pm 53.11$ \\
Adenocarcinomas & $14(82.4 \%)$ & $6(66.7 \%)$ \\
Carcinomas mucinosos & $3(17.6 \%)$ & $3(33.3 \%)$ \\
\hline
\end{tabular}

${ }^{*} p=0,006$ (adenocarcinomas frente a carcinomas mucinosos en el colon izquierdo del grupo); DMH: dimetilhidracina; SD: desviación estándar; n: número de tumores. Los datos entre paréntesis reflejan porcentajes del total. El tamaño tumoral se expresa como la mayor superficie tumoral medida en milímetros cuadrados. 
Se encontraron dos tumores de intestino delgado, uno en una rata del grupo $\mathrm{C}$ y otro en una rata del grupo $\mathrm{E}$. Se registró un tumor ótico en una rata del grupo $\mathrm{C}$.

\section{DISCUSIÓN}

El consumo de etanol es considerado como un posible factor de riesgo para el desarrollo del cáncer colorrectal, tanto en estudios clínicos (5-8) como experimentales en ratas $(16,17)$.

Para estudiar el cáncer de colon controlando las diversas variables que intervienen en su inducción, la carcinogénesis colónica inducida con 1,2 dimetilhidracina $(\mathrm{DMH})$ en ratas es un modelo válido empleado desde hace más de 3 décadas (18-20).

En estudios retrospectivos, se observa un riesgo elevado de cáncer de colon en mujeres a partir de un consumo de 63 g al día (5), mientras que otros trabajos (9) no aprecian dicho incremento, con un consumo diario de $30 \mathrm{~g}$ de etanol. Teniendo en cuenta estos resultados, nuestras ratas recibieron $1,23 \mathrm{~g} / \mathrm{kg}$ de etanol diario durante las $24 \mathrm{se}-$ manas que duró el estudio, lo cual es una dosis de consumo y de riesgo en la población humana. Se trata de un trabajo original, donde se comprueba que el consumo de etanol a la dosis y tiempo establecidos no tiene influencia sobre la carcinogénesis colorrectal.

Con las cantidades de alcohol que se administraron, las ratas no mostraron su rechazo natural al alcohol, así que no era esperable que las diferencias de consumo de etanol entre el grupo E y el grupo control de etanol fueran significativas, como así sucedió.

Los resultados obtenidos en el modelo de carcinogénesis inducida por DMH son variables en función del diseño del estudio. En presencia de alcohol esta es inhibida, mientras que en su ausencia, se estimula debido a una inducción asociada al citocromo P450 (31). Más aún, al usar un carcinógeno primario, el alcohol puede comportarse de forma inversa, estimulando la carcinogénesis (32). Basado en estos resultados la administración de alcohol en nuestras ratas podría haber disminuido la carcinogénesis inducida por DMH; sin embargo, no observamos diferencias significativas en la carcinogénesis colorectal entre los grupos DMH y DMH + etanol.

La dosis de etanol administrada no modificó significativamente el número de ratas inducidas por DMH libres de tumor y tampoco modificó el número de tumores por rata. Algunos autores (32) afirman que no existe relación entre el tamaño tumoral o la estirpe histológica con la presencia de etanol, como observamos en nuestro estudio, pero estos autores relacionan la ingesta de etanol con el mayor número de tumores aparecidos en el recto, efecto que no hemos comprobado en nuestros animales. En nuestro trabajo hemos encontrado que tal consumo de etanol no modificó ni el número de tumores, ni su tamaño, ni la localización de los tumores inducidos por $\mathrm{DMH}$, como han descrito otros autores sobre el mismo modelo (33).
Estudios clínicos llevados a cabo en pacientes con carcinoma colorrectal que bebían alcohol, parecían tener mayores tasas de mortalidad por cáncer, debido a un mayor desarrollo de metástasis hepáticas (34). La ausencia de metástasis hepáticas en nuestras ratas, no nos permiten aportar datos a este respecto.

En estudios in vitro (15) se describe que el consumo de etanol podría provocar una mayor agresividad de los tumores colorrectales; dicha agresividad es descrita en términos de una tasa de proliferación aumentada, con una menor diferenciación celular y una menor adhesión intercelular. Aunque algunos estudios en roedores (35) describen que la ingesta de etanol promueve algunos cambios en el tejido linfoide del epitelio, lo que explicaría un mecanismo promotor cocarcinogénico (28), no se apreció esta relación en nuestras ratas. Nuestros resultados mostraron que no existieron diferencias significativas en cuanto a las características anátomo-patológicas de los tumores inducidos por DMH por efecto del etanol, con lo que dicha agresividad no fue detectada en los tumores de nuestros animales.

En estudios epidemiológicos, el mecanismo por el que el alcohol podría modificar la carcinogénesis colorrectal parece ser dosis-dependiente $(4,5,36)$, aunque otros autores no lo entienden así (37). Tomando todos ellos conjuntamente sugieren que cuanto más prolongada sea la ingesta de etanol, la cantidad diaria necesaria para observar un riesgo incrementado de cáncer colorrectal, es menor. Basándose en esta hipótesis, la explicación de nuestros resultados vendría dada porque el tiempo de duración del estudio habría resultado demasiado breve, aunque un modelo dinámico de administración concomitante de alcohol y procarcinógeno como el utilizado por nosotros podría resultar un diseño controvertido, para el estudio del efecto del etanol sobre la carcinogénesis colónica experimental inducida por la DMH.

Se relata una incidencia de carcinogénesis colónica experimental espontánea de menos de 2-3 ratas / 100.000 ratas observadas (38). En ausencia de carcinógeno (DMH), las ratas no presentaron tumores como se esperaba.

Los tumores colónicos proximales y distales y de recto deben ser considerados como entidades etiopatológicas diferentes, basándonos en estudios epidemiológicos (9) y experimentales en ratas (39); por lo que la respuesta del epitelio en las diferentes localizaciones colónicas puede ser diferente dentro de la misma rata DMH-inducida (16). En este punto, merece la pena destacar la clasificación histológica utilizada, donde la estirpe mucinosa del adenocarcinoma se toma, al agual que en patología humana, como una estirpe poco diferenciada, y con entidad suficiente, y diferente del adenocarcinoma "no mucinoso" (29). Tanto estudios experimentales (40) como revisiones de la literatura (41), asocian la localización derecha de los tumores con la peor diferenciación. En nuestro estudio demostramos que hubo significativamente un mayor número de carcinomas mucinosos en el colon derecho, respecto al colon izquierdo, de las ratas del grupo $\mathrm{DMH}$, 
mientras que únicamente una tendencia hacia este comportamiento fue observada en los tumores de las ratas del grupo DMH+etanol sin llegar a la significación estadística (probablemente porque el número de tumores no fue suficiente). Nuestros datos divergen con los obtenidos por otros autores $(31,42)$ que reflejan que el número de tumores del colon derecho están en relación inversamente proporcional al consumo de alcohol (más frecuentes en colon distal), en un modelo dinámico de carcinogénesis. La dosis de alcohol utilizada en este estudio, resultó, por tanto, insuficiente para mostrar el efecto inhibitorio sobre la carcinogénesis del colon derecho; con lo que los tumores del colon derecho mostraron su habitual peor comportamiento, comparándolos con los del colon izquierdo, como sugieren diversos autores $(40,41)$. Estos resultados no son comparables al de otros autores $(25,43)$, al haber utilizado en este trabajo la clasificación morfológica de Grau de Castro-Piqué Badía (29), y que ha sido comentada y publicada previamente (44).
Concluimos señalando que el suplemento oral con etanol a una dosis de $1.23 \mathrm{~g} / \mathrm{kg}$ peso al día durante 24 semanas: a) no modificó la inducción tumoral en un modelo experimental dinámico de carcinogénesis colónica inducida por DMH a la dosis y tiempo establecidos en ratas Sprague-Dawley; y b) no observamos un comportamiento histológico diferente entre los tumores localizados en el colon derecho y los del colon izquierdo.

\section{AGRADECIMIENTOS}

Los autores quieren expresar su agradecimiento a D. Manuel Santiago por su ayuda técnica en el manejo y cuidado de los animales. Este trabajo de investigación ha sido subvencionado por la Universidad de Lleida y con una Beca de "Ayuda a la Investigación FISS Exp. $n^{\circ}$ 89/0612”. 